\title{
Evaluation of Minerals Content in SolaniumDubium Collected From White Nilein Central Sudan
}

\author{
Ardelshifa Mohammed Elhassan Mohammed \\ Kingdom of Saudi Arabia,Quassim University, College of Science and Art OyunAljiwa
}

\begin{abstract}
:
Some plants of the family solanaceae such as Solanumdubium"Gubbain", which is a well-known wild plant, grow wildly in many regions in Sudan during the rainy season. Solanumdubiumis used in rural areas for milk coagulation. It is a bushy pubescent herb grown widely in northern, central and western Sudan along with other species such as S. innacum, S. esculentum, S. macrocarpon and S. melongena.Research on S. dubium was focused mainly on obtaining Solanum crude enzyme from the seeds in pure form and commercial production of the enzyme for cheese making. Solanaceous plants are known for their high alkaloidal content in all plant parts including the seeds, which are responsible for their antimicrobial activity in addition to other metabolites such as flavonoids and tannins.

This study was conducted to determine the chemical composition of the seeds ofSolanumdubiumplant and its properties.Plant Solanumdubium have been used as milk coagulants in cheese making for centuries either as crude extracts or in purified form. These coagulants are an alternative to the calf rennet due to the limited availability and high price of rennet, religious factors, diet or ban on recombinant calf rennet in some countries. These enzymes are found in almost all kinds of plant tissues and can be obtained from their natural source or through in vitro culture to ensure a continuous supply of plant proteases. The excessive proteolytic nature of most plant coagulants haslimited their use in cheese manufacturing due to lower yields of cheese, bitter flavors and texture defects. The search for new potential milk-clotting enzymes from plants still continues in order to meet the increasing global demand for diversified and good quality cheese production. For the great important uses ofsolanum, the study aim's to focus of the active chemicals component in solanum seeds.

The seeds of Solanumdubium were blended and extracted using different types of buffers. The most reliable, quick, and efficient buffer was found to be 5\% $\mathrm{NaCl}$ in acetate buffer ( $\mathrm{pH} 5.0$ ) which was used throughout the study. The extract was filtered and fractionated twice with ammonium sulphate. When compared with other plant enzymes, S. dubium enzyme was found to have higher clotting and proteolytic activities. The activity of the enzyme was steadily increased with enzyme and substrate concentration. The enzyme was found to be very stable against a wide range of $\mathrm{pH}$ values as well as a wide range of temperature $\left(20-90{ }^{\circ} \mathrm{C}\right)$. The results of substrate specificity of the enzyme showed that the partially purified enzyme preferred both hydrophilic and hydrophobic amino acid residues at P1 position. The catalytic efficiency of the purified enzyme was enhanced by an aliphatic amino acids (Leu) compared to aromatic residue (Phe) at Pl position at the same site. And the morphology of solanum seeds was studied with scanning electron microscopy of mucilage at different magnification using Philips, Lancashire, XL-30 SEM and the results show in figures 5, 6, 7). Also the fractionation of structure was observed with infera red spectroscopy in figure (8).

In this study some metals was determined like $\mathrm{Mn}, \mathrm{Cr}, \mathrm{Cd}, \mathrm{Zn}$., $\mathrm{Fe}$, and basic element like $\mathrm{Ca}, \mathrm{Mg}, \mathrm{K}, \mathrm{P}$ in solanum seeds, the sample observed that maximum permitted levels is $K$ higher concentration one and other metal flow respectively $\mathrm{Ca}, \mathrm{Cr}, \mathrm{Fe}, \mathrm{Cd}, \mathrm{Zn}$, and $\mathrm{P}$.Seed samples of solanumcollected fromKenana area in white Nile. Metal concentrations found in solanum seeds are shown in Table 2 and Table 3. The study showed significant positive correlation metal content in solanum contain including heavy metals. The results showed that all chemical components under study were not significantly affected by the type of coagulant insolanum uses in cheeseindustry.
\end{abstract}

Keywords:plant Solanumdubium, (Gubbien) seed, chemical element, enzymedubumin, solventextraction.

\section{Introduction}

Solanum is a large and diverse genus of flowering plants, which include two food crops of high economic importance, the potato and the tomato. It also contains the nightshades and horse nettles, as well as numerous plants cultivated for their ornamental flowers and fruit.

Solanum species show a wide range of growing habits, such as annual and perennials, vines, subshrubs, shrubs, and small trees. Many formerly independent genera like Lycopersicon (the tomatoes) and Cyphomandra are now included in Solanum as subgenera or sections. Thus, the genus today contains roughly 1,500-2,000 species $(20,17,28)$. 

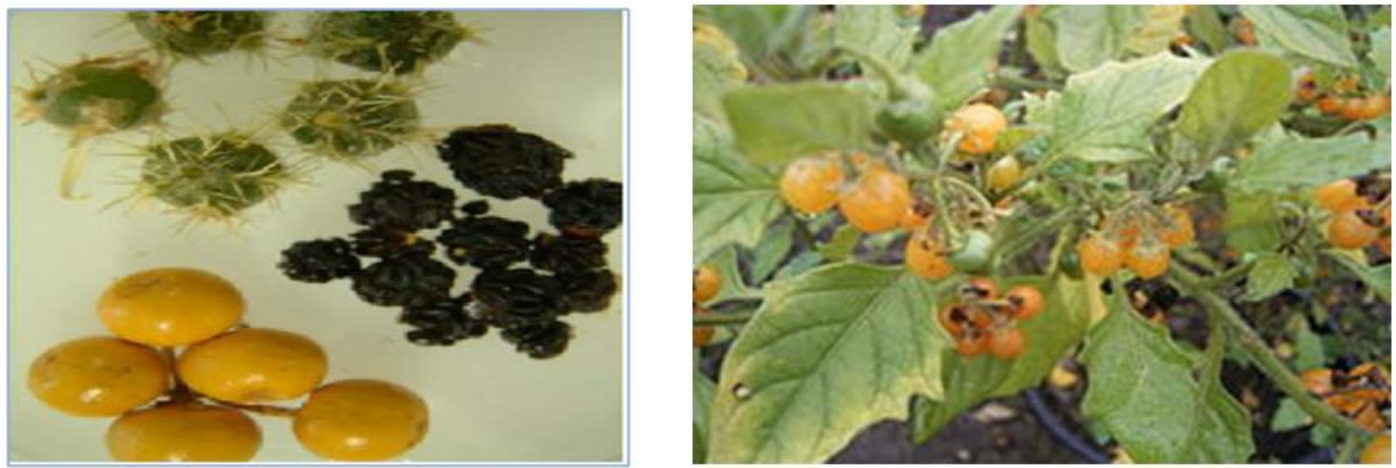

Fig. 1. Solanumdubium whole plant (left), fruits (yellow and green) and seeds (black clusters)

\begin{tabular}{|l|l|}
\hline \multicolumn{2}{|l|}{ Scientific classification } \\
\hline Kingdom: & Plantae \\
\hline (unranked): & Angiosperms \\
\hline (unranked): & Eudicots \\
\hline (unranked): & Asterids \\
\hline Order: & Solanales \\
\hline Family: & Solanaceae \\
\hline Genus: & Solanum \\
\hline Species: & S. dubium \\
\hline
\end{tabular}

\section{Binomial nameSolanumdubium}
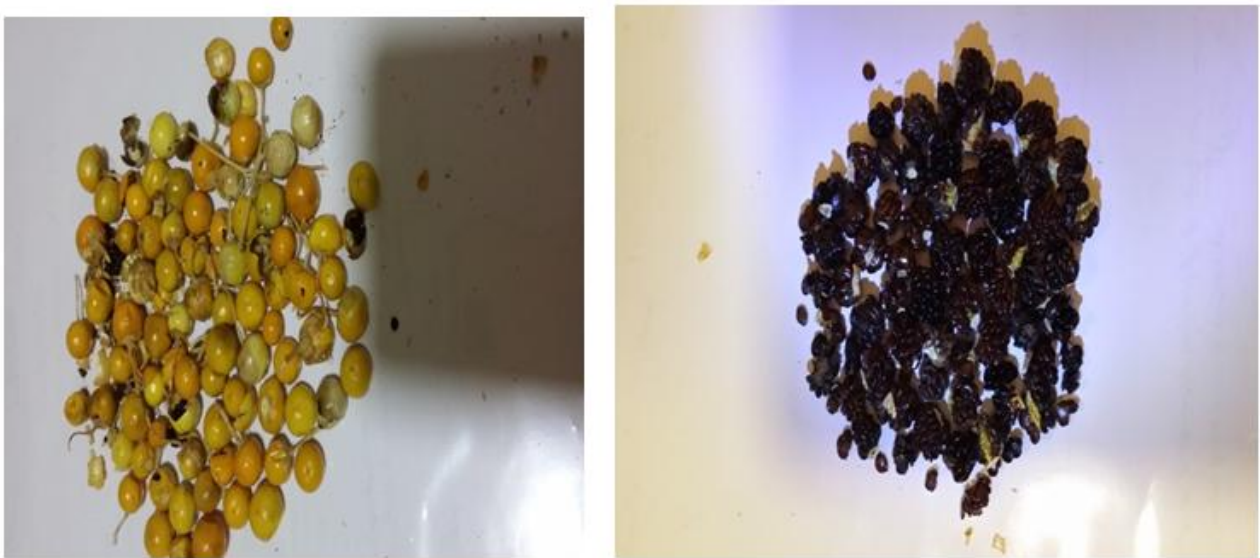

Fig. 3.The fruits with coat and see of Solanumdubium

The genus Solanum consists of over 2000 species distributed worldwide is the largest member of the Solanaceae and is one of the largest genera among all flowering plants (19). The species of the family Solanaceae are medicinal herbs (6), and contain unique alkaloids and other biochemical constituents used for the treatment of diverse ailments such as diabetes, cholera, bronchitis, high blood pressure and as laxatives (8).

\subsection{Plant and uses}

Solanumdubiumfresen is an indigenous plant wildly grown in central, northern and western Sudan, it is a woody herb, unripe fruits are greencolor, while the ripe ones are yellow, and fruits usually dry on the stem. The seed is dark brown in color, and due to its bitter taste animals do not eat it. Dairy farmers in some parts of the Sudan use the berries of Solanumdubiumto make white soft cheese known as GibnaBaydafrom goat and sheep milk $(29,28)$.

The resultant cheese has a slight bitter taste and a fragile crumbly texture, and the bitterness being caused by the presence of some alkaloids or nonspecific proteolytic activity of enzymes that is obtained from the berries of Solanumdubium(3). No attempt has been made in Sudan to investigate the production of Mudaffaracheese from plant enzyme $(1,2,4)$.

It animal rennet is not available or slaughter od calves for chymosin is not feasible or the cheese is only for vegetarians, vegetable rennet becomes very important and the use of vegetable rennet for cheese making could contribute to improving the nutrition of those populations whereas restriction are imposed against the use of animal rennet $(2,6,8,15,19)$.

Plant source for milk clotting enzymes had been identified from different plants including Solanumdubium. Solanumdubiumis a well-known species belonging to the family Solanaceae (Suleiman et al. 
1988). It is also described as a bushy pubescent herb plant distributed in different regions in Sudan. The $S$. dubium fruit was found to have a high concentration of rennin-like compound (9) that has been used for white cheese production purposes. Some research showed positive results using Solanumtorvumand Solanum dubium for the manufacture of white cheese $(3,5,4,20)$

Dawla (2001) found that cheese produced using rennin extracted from S. dubium is characterized by its light, soft and compact texture, preferentially better than that produced using commercial rennin materials. Recently, much research interest has been directed towards discovering a milk-clotting enzyme from natural plants that could satisfactorily replace commercial rennet in cheese making (14). In general, callus (unorganized aggregate of cells) can be induced from an excised part of a plant (explants) in which callus growth after culturing of the explants can be continued and regeneration of whole plants (plantlets) can be readily obtainable

Their research showed positive results in using this extract for manufacture of Sudanese white soft cheese. This research aims to study the chemicals component and their characterization of Solanumdubiumseeds $(5,9,16,27)$.

\subsection{Solanumdubiumanantioxidants:}

In the light of recent scientific developments, the medicinal properties of plants have been investigated, throughout the world due to their potent pharmacological activities and economic viability. A great number of aromatic and medicinal plants contain compounds, exhibiting antioxidant property. The natural antioxidants are primarily plant phenolic compounds that may occur in all parts of plants such as fruits, vegetables, nuts, seeds, leaves, roots and barks (Pratt, 1990). Many of these antioxidant compounds possess anti-inflammatory, antiatherosclerotic, antitumor, anticarcinogenic, antibacterial or antiviral activities to a greater or lesser extent (Sala et al, 2002). Crude extracts of fruits, herbs, vegetables, cereals and other plant materials rich in phenolicare increasingly of interest in food industry, because they retard oxidative degradation of lipids and thereby improve the quality and nutritive value of food (Kahkonenet al, 1999; Rice et al, 1995).

Solanumdubium can mixture with honey to raise the activity for uses in industry of cheese and medicine .The curative potential of honey is well documented in the oldest medical literatures and religious testaments. At the research level, honey is currently showing potential in minimizing cellular injuries of the skin and post-radiotherapies $(21,9,16)$.

\subsection{Sample of Solanumdubiumplant}

\section{Materials And Methods}

The plants were collected from Kenana area,Wight Nile in central of Sudan between December 2016 and January 2017. The coats and seeds were separatedand carefully cleaned, washed several times withdistilled water and the coats were then coarselypowdered using electric grinder. The coats wereanalyzed to determine dry matter, ether extract, crudeprotein, crude fiber and ash. The cleaned and shade-dried plant seeds were powdered using a grinding machine; each ground sample was weighed and stored in a dry container at ambient temperature.

And the seed powder after crushed was analyzed to determinetheir chemical components.

\subsection{Preparation of samples:}

All samples were treated chemically to allow measuring of concentrations of $\mathrm{Ca}, \mathrm{Fe}, \mathrm{Zn}, \mathrm{P}, \mathrm{Cd}, \mathrm{Mn}, \mathrm{Cr}, \mathrm{K}$, and Mgcontent in the parts of plant using different instruments. The parts of solanum plant were dried and grinded softly in a ceramic mortar and sieved. The powdered kept in bottles to use in next steps.

\subsubsection{Sample preparation for AAS:}

The parts of solanum plant were dried and grinded softly in a ceramic mortar and sieved. $0.5 \mathrm{~g}$ of the sample was placed into $100 \mathrm{ml}$ Teflon beaker, $6 \mathrm{ml}$ of (1:5) per chloric acid and nitric acid were added and allowed to stand at room temperature overnight for initial the reaction, and subsequently $10 \mathrm{ml}$ of concentration $\mathrm{HClO} 4$ were added to the mixture .The Teflon beaker was tightly stopping (to reflux the vapours of the acid) and heated on sand bath at200-250 c for at least 6 hours until complete digestion was achieved, which is indicated by anon turbid and/or a white solution. Then the solution was evaporated to dryness or semi dryness. The residue was diluted with distilled water into $50 \mathrm{ml}$ volumetric flask. The prepared solution was placed in to $50 \mathrm{ml}$ of polyethylene bottle and stored at room temperature to be ready to use for AAS within 30 days.

\subsubsection{Preparation Solanumdubiumseed extract}

Ten grams of the crushed seed were shaken with $100 \mathrm{ml}$ distilled water and then the mixture wasblended by agitator for $15 \mathrm{~min}$ until the mixturebecame homogeneous. Seed extract was placed in therefrigerator at $4^{\circ} \mathrm{C}$ for $24 \mathrm{hr}$, filtered and $20 \mathrm{ml}$ of theextract was used for analysis.

\subsection{Scan electron microscopy (SEM) of solanumdubium seeds:-}

Solanumdubium samples were placed on brass analysis stubs and placed into a JEOL JSM-6380LV SEM. The samples were run as received without any coating or processing. The microscopy power was kept low (to prevent imaging problems) and images were taken at varying magnifications under vacuum (figures 5,6 and 7). 


\subsection{Fourier transform analysis}

Fourier Transform Analysis (FTIR) spectra of mucilage were recorded on a FT-IR spectrometer (Thermo Scientific). The dry powder was mixed with $\mathrm{KBr}$ and pressed into pellets under mechanical pressure. The FT-IR spectra were obtained by scanning between 4000 and $500 / \mathrm{cm}$.

\subsection{Extraction of Solanum dubium seed :}

The crude enzyme was extracted by the following methods:-

Freezing and evaporating under reduced pressure (freezing drying):-

Coarsely powdered yellow fruits and seeds (100g each ) were macerated in conical flask for 24 hour using distilled water with occasional shaking for the first three hours and solutions were then filtered .The filtrate was spread on shallow basin surrounded by afreezing mixture under vacuum for water evaporation within two hours $(13,25,10)$.

\subsubsection{Extraction with distilled water:-}

Five grams of the crushed material were shacken with $30 \mathrm{ml}$ distilled water for 15 minutes at room temerature and then filtered. The aqueous filtrate was used for determined the enzyme activity and concentration $(22,25)$.

\subsubsection{Preparation of $96 \%$ ethanol, methanol and water extracts}

Five hundred grams of sample, S. dubium seeds combination was extracted by maceration with $96 \%$ ethanol using shaker apparatus. Extraction was carried out for three days with daily filtration. The filtrates were combined and the solvent was evaporated under reduced pressure using a rotary evaporator. The same procedure was repeated with methanol $(10,13$, and 21$)$

\section{Results and Discussion}

The present study was conducted to investigate the enzyme extract and to identify metals, content in Sudanese $S$. dubium seed (27).

The chemical composition of Solanum dubium coat was as follows:

crude fiber $57.9 \%$, crude protein $12 \%$, dry matter $97.05 \%$, ash $8.5 \%$, nitrogenfree extract $10.89 \%$, fat $5.78 \%$. The chemical composition of black cumin was as follows: crude fiber $27.25 \%$, crude protein dry matter $95.32 \%$, ash $3.40 \%$, fat $19.12 \%$, nitrogen free extract $15.30 \%$.

Table(1)Substrate specificity of Solanum dubium enzyme on different peptide substrates.

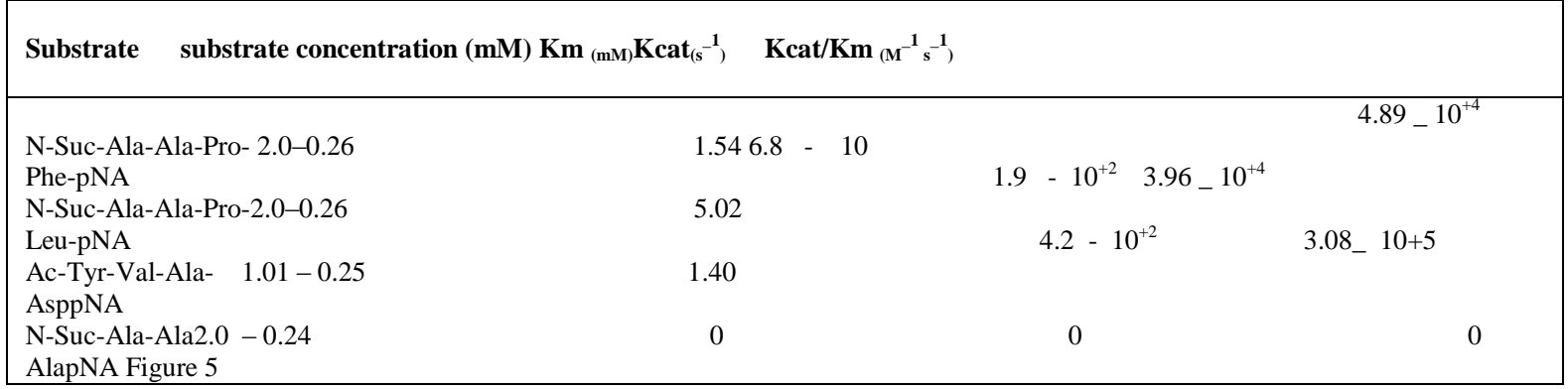

\subsection{Scan electron microscopy (SEM) :-}

Scanning electron microphotographs (SEM) of mucilage obtained is represented in Figure 5, 6, 7 at different magnifications. The microphotographs of mucilages are indicative of an amorphous material. The particles are mostly seen as aggregates of irregular shapes and dimensions which were fibrous in nature. The SEM results of the present study suggest that, hydration capacity of mucilage depends on the surface property. The shape and structure or surface topography of the mucilage may be affected by the method of extraction and purification or preparation of the products reported that, particle size and specific surface area influence the hydration behavior of solanum, which in turn influence their intrinsic and molecular mass. They also reported that particle size influenced the hydration kinetics and molecular mass of solanum dubium. 

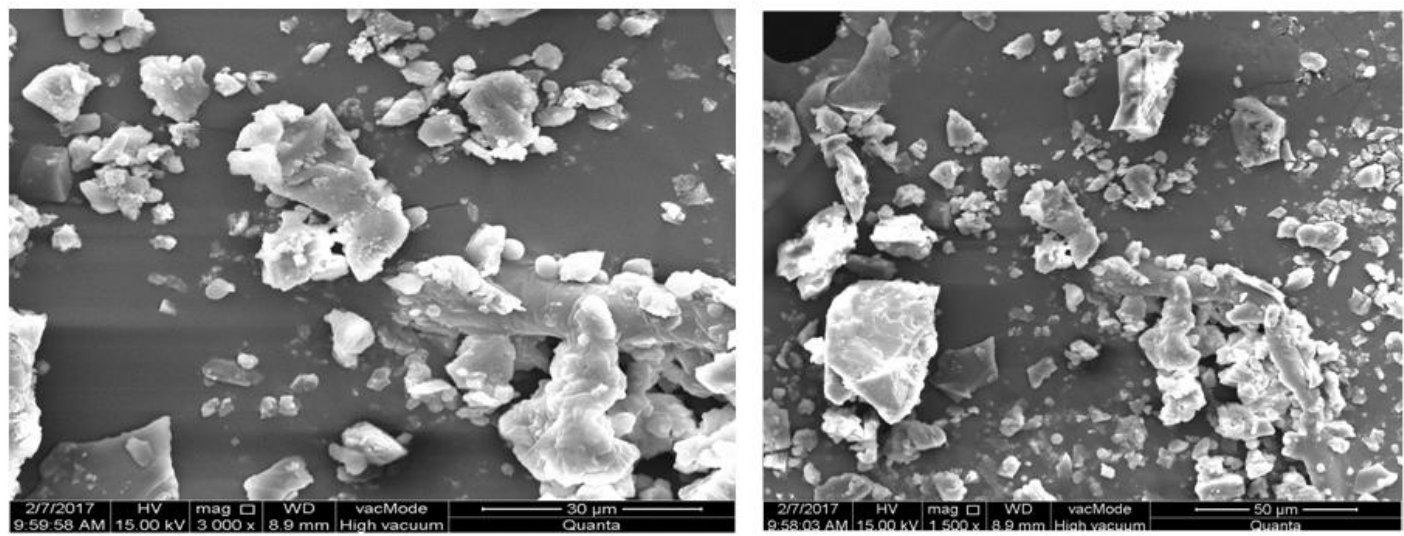

Figure (5) and (6)SEM of solanum seeds in high vacuum

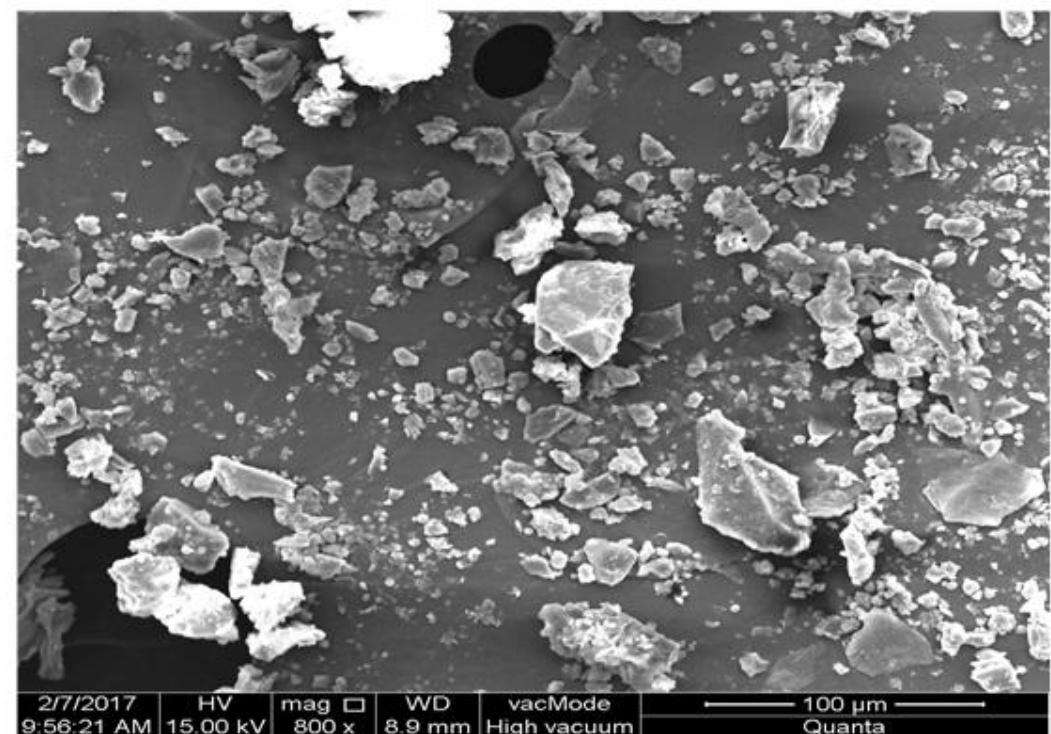

Figure 7-solanum seedsScanning electron microscopy of mucilage at different magnification using Philips,

\subsection{Infera red spectroscopy of solanum dubium}

Lancashire, XL-30 SEM.

Fourier transform analysissoftware was used to interpret. Spectra exhibited the typical bands and peak characteristic of solanum. The spectra of mucilage shows band occurring at $2924.06 \mathrm{~cm}^{-1}$-results from the presence of $2809 \mathrm{~cm}^{-1}$ results from stretching modes of the alkyl C-H stretch or $\mathrm{CH}_{2}$, carboxylic acid C= FTIR spectrometry has been extensively applied to characterize the polymer's molecular and material structure. Characterization using FTIR spectroscopy often results in the identification of functional groups and the modes of their attachment to polymer backbone (Baxter et al., 1992). The FTIR spectra exhibit the typical bands and peak characteristic for mucilage. The FT-IR spectrum of mucilage is presented in Figure 8. 'CHEMIX' School O methylene $\left(-\mathrm{CH}_{2}-\right) \mathrm{C}-\mathrm{H}$ stretch. The peak obtained at $1635.24 \mathrm{~cm}^{-1}$ results from stretching mode of the alkenyl $\mathrm{C}=\mathrm{N}$ and $\mathrm{C}=\mathrm{C}$ stretch. Absorption bands around 1635.24 and $1379.30 \mathrm{~cm}^{-1}$ is $\mathrm{CH} 3$ or $\mathrm{C}-\mathrm{H}$ methyl rock. Also absorption peaks at $1745.14 \mathrm{~cm}^{-1}$ result of $\mathrm{C}=\mathrm{O}$. The band 1160.80 is $\mathrm{CO}$ or $\mathrm{S}=\mathrm{O}$ sterch. The band 720.16 $\mathrm{CH}_{2}$ rocking and 563.50 band is $\mathrm{C}=\mathrm{C}$. 


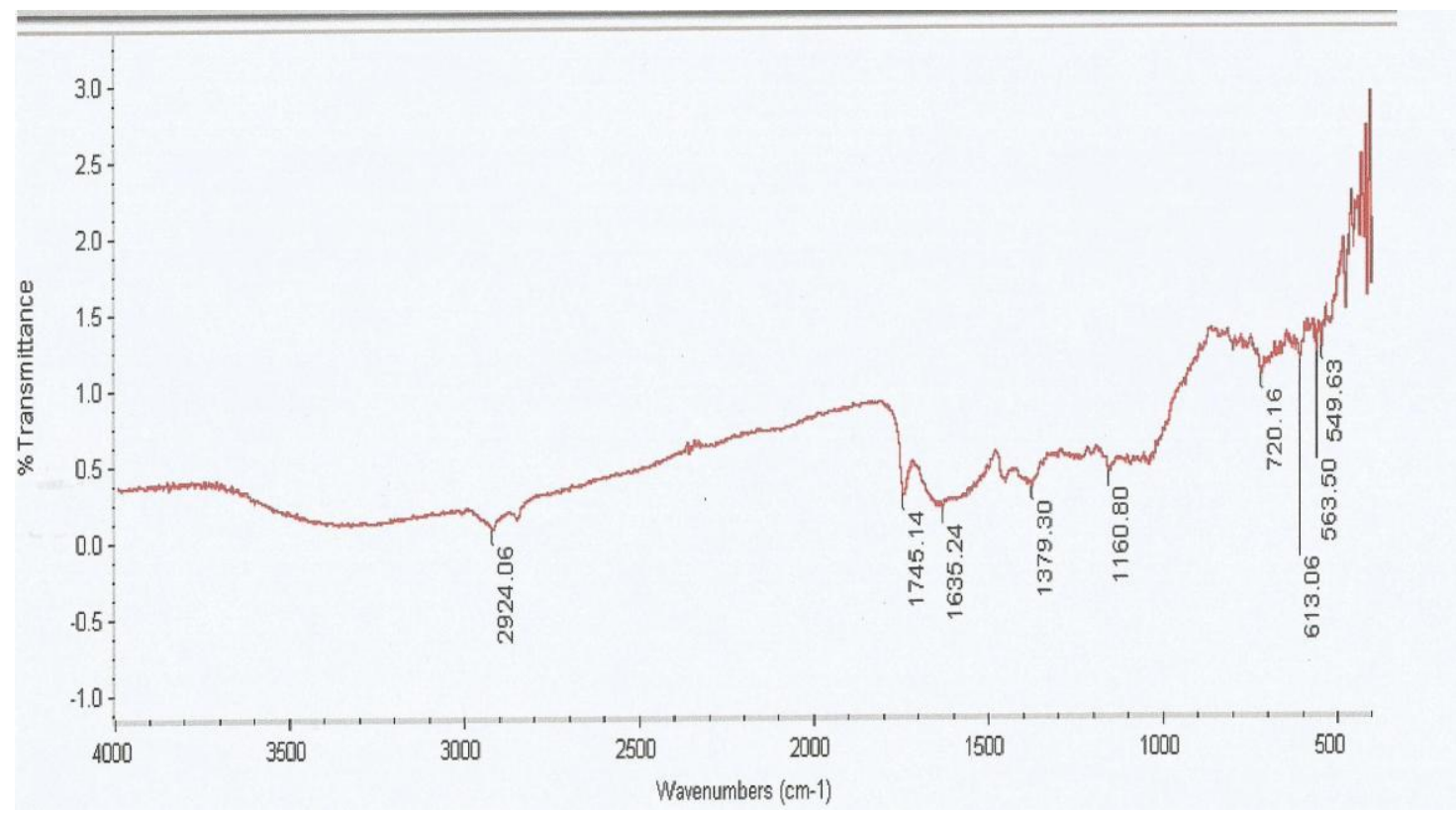

Figure (8)infera red spectroscopy of solanum dubium

\section{3-3 results ofmetals analysis:}

Metal content in tobacco depends on soil properties, atmospheric conditions, and requirements for solanum farming (useof pesticide and fertilizer). Solanum plants take up Potassium and Calcium from soil and concentrate these metals in leaves. Forthis reason, there are large variations in the content of metals in tobacco between countries.

In this study content of $\mathrm{Mn}, \mathrm{Cr}, \mathrm{Cd}, \mathrm{Zn}$. , Fe, and basic element like $\mathrm{Ca}, \mathrm{Mg}, \mathrm{K}$, Pin solanum seedswas determined, the sample observed that maximum permittedlevels its $\mathrm{K}$ it higher concentration one and other metal flow respectively $\mathrm{Ca}, \mathrm{Cr}, \mathrm{Fe}, \mathrm{Cd}, \mathrm{Zn}$, andP,but all of them are found higher concentration in solanum seed samples collected from Kenana area in Wight Nile. Metalconcentrations found in solanum seeds are shown in Table 2 and Table 3 The study showed significant positivecorrelation metal content in solanum contain including heavy metals .

A significant positive correlation was observed between metals content in solanum. These results suggest the possibilitythat the higher concentration of metals in solanum refer to the origin from source.

Table (2 )concentration of metals in solanum dubium

\begin{tabular}{|l|l|l|l|l|}
\hline Element & Element Symbol & Wavelength $(\mathrm{nm})$ & Lamp Current Low $(\mathrm{mA})$ & Slit Width (nm) \\
\hline Calcium & $\mathrm{Ca}$ & 422.7 & 10 & 0.5 \\
\hline Magnesium & $\mathrm{Mg}$ & 285.2 & 8 & 0.5 \\
\hline Manganese & $\mathrm{Mn}$ & 279.5 & 10 & 0.2 \\
\hline Chromium & $\mathrm{Cr}$ & 357.9 & 10 & 0.5 \\
\hline Cadmium & $\mathrm{Cd}$ & 228.8 & 8 & I.0 \\
\hline Zinc & $\mathrm{Zn}$ & 213.9 & 8 & 0.5 \\
\hline Ferric & $\mathrm{Fe}$ & 248.3 & 12 & 0.2 \\
\hline Potassium & $\mathrm{K}$ & $582.0(\mathrm{ppm})$ & - & - \\
\hline Phosphorus & $\mathrm{P}$ & $12.0(\mathrm{ppm})$ & - & - \\
\hline
\end{tabular}

Table (3 ) Atomizer / Gas Flow Rate Setup

\begin{tabular}{|l|l|l|l|l|l|l|}
\hline Element & $\begin{array}{l}\text { Element } \\
\text { Symbol }\end{array}$ & $\begin{array}{l}\text { Fuel gas flow } \\
\text { rate }(\mathrm{L} / \mathrm{min})\end{array}$ & Flam type & $\begin{array}{l}\text { Burner } \\
\text { Height(mm) }\end{array}$ & $\begin{array}{l}\text { Burner lateral } \\
\text { pos.(pulse) }\end{array}$ & $\begin{array}{l}\text { Burner angle } \\
(\text { degree })\end{array}$ \\
\hline Calcium & $\mathrm{Ca}$ & 2.0 & Air- $\mathrm{C}_{2} \mathrm{H}_{2}$ & 7 & 0 & 0 \\
\hline Magnesium & $\mathrm{Mg}$ & 1.8 & Air- $\mathrm{C}_{2} \mathrm{H}_{2}$ & 7 & 0 & 0 \\
\hline Manganese & $\mathrm{Mn}$ & 2.0 & Air- $\mathrm{C}_{2} \mathrm{H}_{2}$ & 7 & 0 & 0 \\
\hline Chromium & $\mathrm{Cr}$ & 2,8 & Air- $\mathrm{C}_{2} \mathrm{H}_{2}$ & 9 & 0 & 0 \\
\hline Cadmium & $\mathrm{Cd}$ & 1.8 & Air- $\mathrm{C}_{2} \mathrm{H}_{2}$ & 7 & 0 & 0 \\
\hline Zinc & $\mathrm{Zn}$ & 2.0 & Air- $\mathrm{C}_{2} \mathrm{H}_{2}$ & 7 & 0 & 0 \\
\hline Ferric & $\mathrm{Fe}$ & 2.2 & Air- $\mathrm{C}_{2} \mathrm{H}_{2}$ & 9 & 0 & 0 \\
\hline
\end{tabular}


Table (4) Measurement Parameters

\begin{tabular}{|l|l|l|l|l|l|l|l|l|}
\hline Element & $\begin{array}{l}\text { Element } \\
\text { Symbol }\end{array}$ & order & Zero Intercept & $\begin{array}{l}\text { Conc } \\
\text { Unit }\end{array}$ & $\begin{array}{l}\text { Repetition } \\
\text { Sequence }\end{array}$ & $\begin{array}{l}\text { Pre-spray } \\
\text { time(sec) }\end{array}$ & $\begin{array}{l}\text { Integration } \\
\text { time(sec) }\end{array}$ & $\begin{array}{l}\text { Response } \\
\text { time }\end{array}$ \\
\hline Calcium & $\mathrm{Ca}$ & $1 \mathrm{st}$ & No & $\mathrm{Mg} / \mathrm{L}$ & SM-M-M & 3 & 5 & 1 \\
\hline Magnesium & $\mathrm{Mg}$ & $1 \mathrm{st}$ & No & $\mathrm{Mg} / \mathrm{L}$ & SM-SM & 3 & 5 & 1 \\
\hline Manganese & $\mathrm{Mn}$ & $1 \mathrm{st}$ & No & $\mathrm{Mg} / \mathrm{L}$ & SM-SM & 3 & 5 & 1 \\
\hline Chromium & $\mathrm{Cr}$ & $1 \mathrm{st}$ & No & $\mathrm{Mg} / \mathrm{L}$ & SM-SM & 3 & & 5 \\
\hline Cadmium & $\mathrm{Cd}$ & $1 \mathrm{st}$ & No & $\mathrm{Mg} / \mathrm{L}$ & SM-SM & 3 & 5 & 1 \\
\hline Zinc & $\mathrm{Zn}$ & $1 \mathrm{st}$ & No & None & SM- SM- & 3 & 5 & 5 \\
\hline Ferric & $\mathrm{Fe}$ & $1 \mathrm{st}$ & No & None & SM-M-M & 3 & 5 & 5 \\
\hline
\end{tabular}

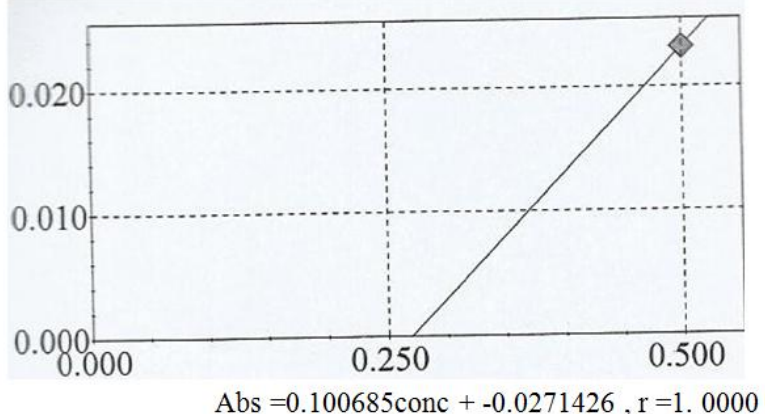

Figure (9)calibration curve of calcium concentration in solanum dubium

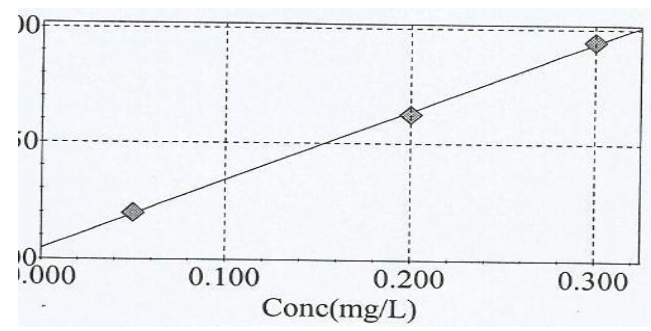
Conc
$(\mathrm{mg} / \mathrm{L})$
0.2000
Abs
0.3000
0.3129
0.0500
0.4719
0.0985

Abs $=1.48853$ conc $+0.0215368, r=0.9996$

Figure (10) calibration curve of magnesium concentration in solanum dubium

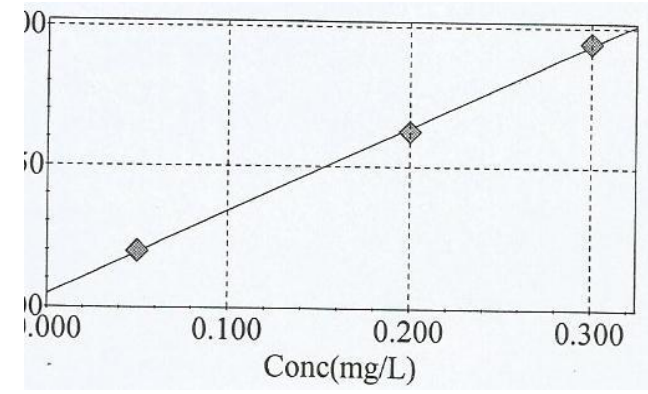

Conc Abs

$(\mathrm{mg} / \mathrm{L})$

$0.2000 \quad 0.3129$

$0.3000 \quad 0.4719$

$0.0500 \quad 0.0985$

Abs $=0.933595$ conc $+0.00472671, r=0.9992$

Figure (11) calibration curve of manganese concentration in solanum dubium

Abs

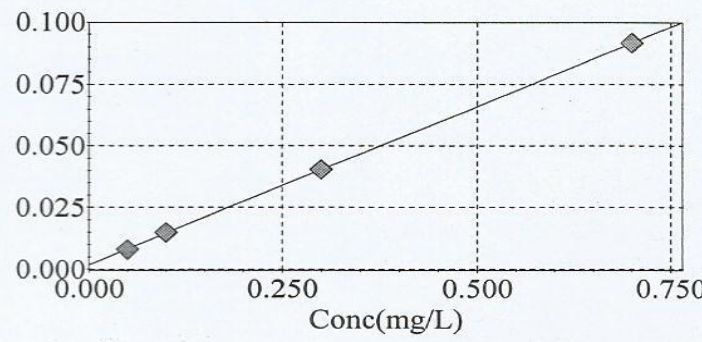

Conc Abs

(mg/L)

$0.1000 \quad 0.0150$

$0.3000 \quad 0.0404$

$\begin{array}{ll}0.7000 & 0.0917\end{array}$

$0.0500 \quad 0.0080$

$\mathrm{Abs}=0.128377 \mathrm{Conc}+0.00186659$

$r=1.0000$

Figure (12) calibration curve of cadmium concentration in solanum dubium 
Abs

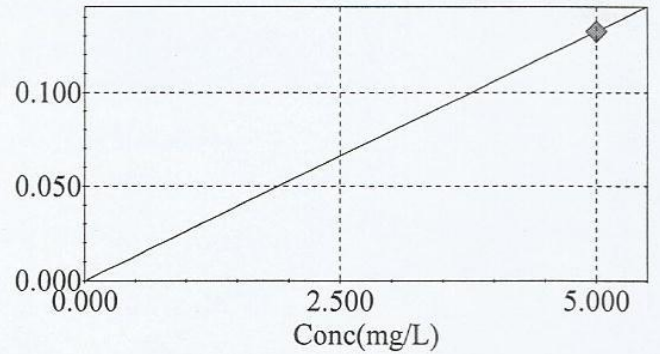

Conc

$(\mathrm{mg} / \mathrm{L})$

5.0000
Abs

0.1325

Abs $=0.0265695$ Conc +-0.000347645

$\mathrm{r}=1.0000$

Figure (13) calibration curve of chromium concentration in solanum dubium

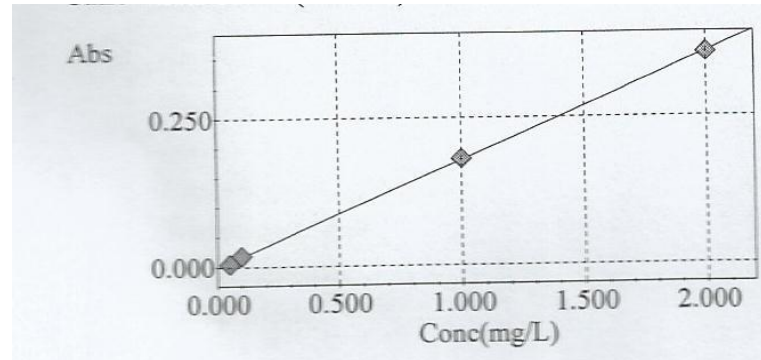

Conc Abs

$(\mathrm{mg} / \mathrm{L})$

$0.0500 \quad 0.0042$

$0.1000 \quad 0.0179$

$2.0000 \quad 0.3569$

$1.0000 \quad 0.1800$

Abs $=0.179941$ Conc +-0.00195334

$\mathrm{r}=0.9999$

Figure (14) calibration curve of zinc concentration in solanum dubium

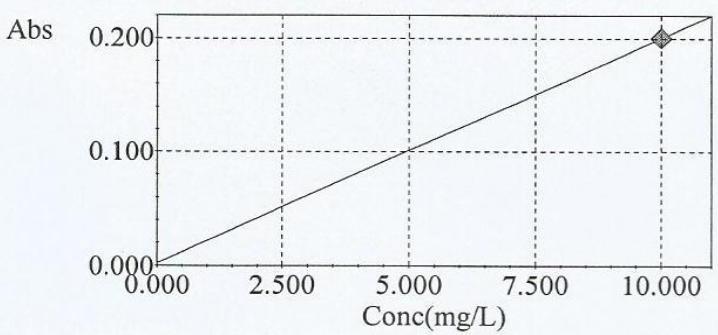

Conc Abs

$(\mathrm{mg} / \mathrm{L})$

$10.0000 \quad 0.2003$

\section{Abs $=0.0198023$ Conc +0.00227724}

$\mathrm{r}=1.0000$

Figure ( 15) calibration curve of ferric concentration in solanum dubium

\subsection{Effect of $\mathrm{pH}$ and temperature on the activity and stability of the purified enzyme.}

(a) PH stability of the purified enzyme. The enzyme $(12 \mu \mathrm{g})$ was incubated atvarious $\mathrm{pH}$ values for 1 or $25 \mathrm{~h}$ at $37^{\circ} \mathrm{C}$. Residual activity was measured after $40 \mathrm{~min}$ at $30^{\circ} \mathrm{C}$ and $\mathrm{pH} 8.0$. (b) Effects of $\mathrm{pH}$ on the activity of the purified protease (14).Enzyme activity was determined using $1 \%$ azocasein as substrate at variousranges of $\mathrm{pH}$ $5.0-12.8$ at $30^{\circ} \mathrm{C}$ for $30 \mathrm{~min}$. The buffer used for $\mathrm{pH} 5.0-6.0$ was $50 \mathrm{mM}$ acetate/ Phosphate, for $\mathrm{pH} 6.0-8.0$ it was $50 \mathrm{mM}$ Tris- $\mathrm{HCl}$, and for $\mathrm{pH} 8.0-12.5$ it was $50 \mathrm{mM}$ glycine- $\mathrm{NaOH}$.

\subsection{Effect of pH on partially purified enzyme activity}

As shown in Fig (16), the purified enzyme is stable under a wide range of $\mathrm{pH}$ and it retained all of its activity in the $\mathrm{pH}$ range from dubium seeds for milk-clotting. However, further purification is required to get a highly pure enzyme $(11,14)$. 


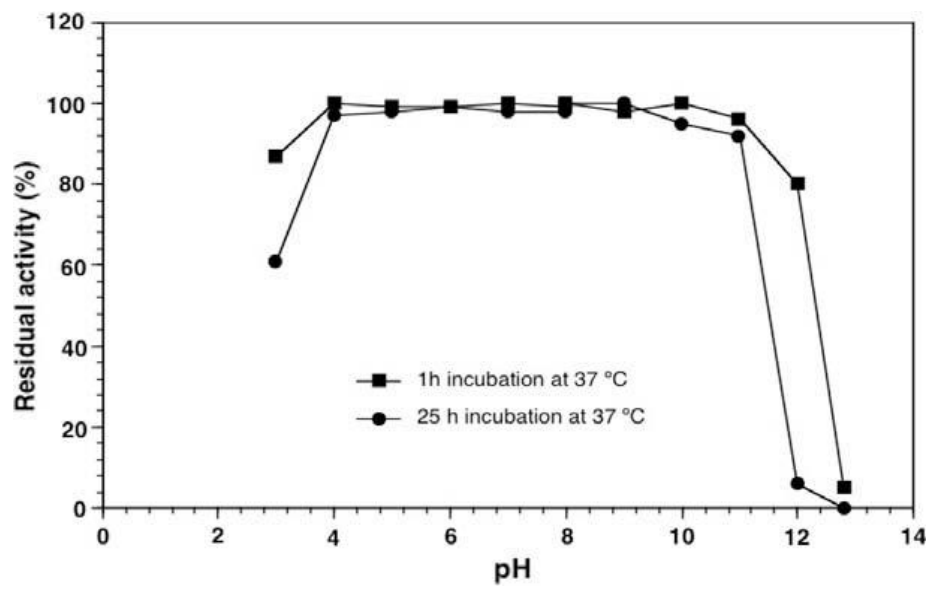

Figure (16)Effect of $\mathrm{pH}$ on the stability of partially purified enzyme from Solanumdubium seeds. .6. Effect of Temperature on partially purified enzyme activity

The results obtained in Fig. 16 showed that the enzyme activity increased as the temperature increased from 20 to $70 \_$C. The activity at 70_C was 5- and 10-fold higher than that of the activity at 40 and $20 \_$, respectively. The activity rapidly decreased as the temperature raised over 80 _C. Since the enzyme had a high optimumtemperature, its stability at a temperature ranged from 20 to 90 _C was studied. There was a total retention of activity after $1 \mathrm{~h}$ incubation at $60 \_\mathrm{C}$ and about $70 \%$ of its activity was retained at $70 \_\mathrm{C}$ when the enzyme was incubated for $1 \mathrm{~h}$. The thermo stability of the enzyme was found to be up to 70 _C. The temperature profile of the enzyme was agreed with those of subtilisin/cucumisin likeplant serine proteases reported by AsifUllah et al. (2006), Yamagataet al. (1989), and Uchikoba et al. (1990).

In conclusion, compared to other purification procedures done we concluded that a simple purification procedure has been developed in this study to obtain a very active and stable enzyme from S. dubium seeds for milk-clotting. However, further purification is requiredto get a highly pure enzyme $(11,14,27)$.

\section{Enzyme activity and stability}

Coagulants should not be sensitive to variations in milk composition and $\mathrm{pH}$, sincethe use of highly $\mathrm{pH}$-sensitive rennet can lead to reduced yields and defective cheese due to soft coagulum at cutting (Harboe and Budtz, 1999). S. dubium milk-clotting enzyme is stable under wide range of $\mathrm{pH}$ (4.0 11.0), and act optimally at pH11.0 (Fig17). The isolated enzyme is more stable at basic $\mathrm{pH}$, and its stability is more comparable to those of Cucumisin-like serine proteases from Cucumis trigonus Roxburghi, Cucumis melo L. var. Prince, Euphorbia milii, and trichosantuskirrilowiA (Asif-Ullah et al., 2005; Yamagataet al., 1989; Yadav et al., 2006; and Uchikobaet al., 1990), respectively. These characteristics are important, because most enzymes are catalytically unstable at alkaline $\mathrm{pH}$ values, thus limiting their usefulness as cheese making coagulants (Lamas et al.,2001) $(20,27)$.

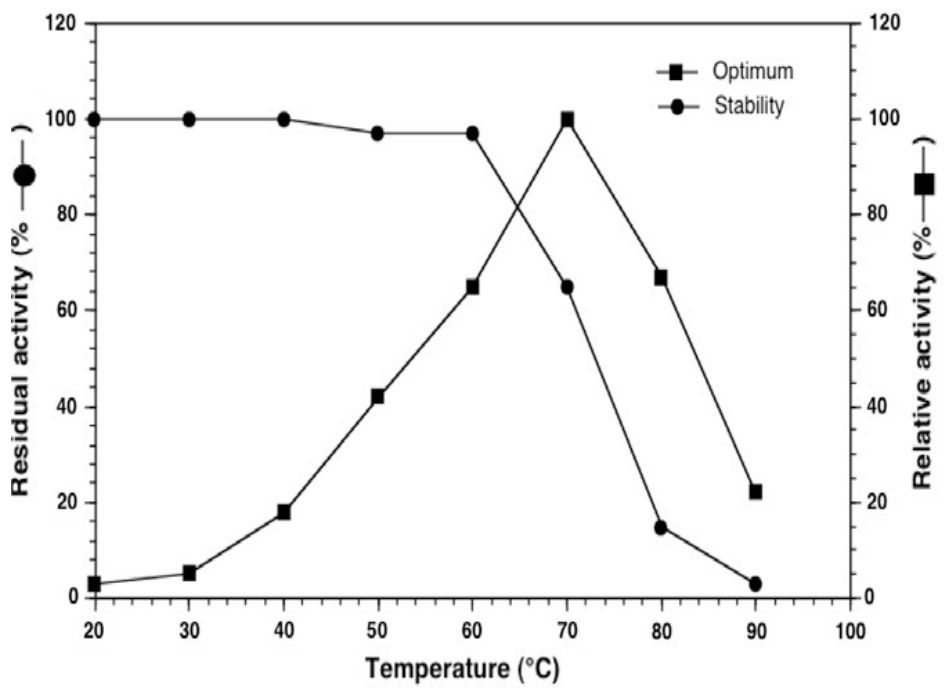

Figure (17) .Effect of temperature on the activity and stability of partially purified enzyme from Solanumdubiumseeds 


\section{Conclusions}

The study show that the content of mineralsMn, $\mathrm{Cr}, \mathrm{Cd}, \mathrm{Zn}$. , Fe, and basic element like $\mathrm{Ca}, \mathrm{Mg}, \mathrm{K}$, $\mathrm{P}$ in solanum seeds, the sample observed that the maximum permitted levels is $\mathrm{K}$ higher concentration one and other metal flow respectively $\mathrm{Ca}, \mathrm{Cr}, \mathrm{Fe}, \mathrm{Cd}, \mathrm{Zn}$, and $\mathrm{P}$ but all of them are found higher concentration in solanum. A seed sample of solanum was collected from Kenana area in Wight Nile. Metal concentrations found in solanum seeds are shown in Table 2 and Table 3 The study showed significant positive correlation metal content in solanum contain including heavy metals .

The results illustrate that all chemical components under study were not significantly affected by the type of coagulant in solanum uses in cheese industry. But must be care by take small weight when we using the solanium seeds powder in cheese industry. 'The extraction of the enzyme by distilled water produced higher activity, and increase in soaking time reduced the activity. As the fruit changes to dry yellow the activity increases. While milk temperature (up to $80^{\circ} \mathrm{C}$ ) increases activity, preheating temperature (up to $80^{\circ} \mathrm{C}$ ) decreases the activity, and the incubation temperature (up to $80^{\circ} \mathrm{C}$ ) and volume of extract (up to $1 \mathrm{ml}$ ) increases the activity.

And the enzyme extracted from solanum is good alternative enzyme and cheap for peoples can use it in all kind of cheeses industry.The researcher recommended continuing the research insolanumdubium to determine the other active compounds and to developing the methods and technic for purification and separation the seed from coat.Also to discovery the structure of solanumdubiuminenzyme.

\section{References}

[1]. Abdalla, M.O.M.; Kheir, O.E.S., and El Owni, O.A.O. (2011). Effect of storage period on quality of Sudanese white cheese (GibnaBayda) manufacturedwith Solanumdubium extract. U. of K. J. Agric. Sci., 19 (2): 202-217.

[2]. Abdalla, M. O. M., Ali A. A. D.; Mohamed, E. B. (2010). Extraction, milk-clotting activity measurements and purification of SolanumdubiumFresen (Gubbain) for cheesemaking. World J. Dairy Food Sci., 5 (2): 152-159.

[3]. Ahmed, I.A.M., I. Morishima, E.E. Babiker and N. Mori, 2009a. Dubiumin, a chymotrypsin-like serine protease from the seeds of SolanumdubiumFresen. Journal of Phytochemistry, 70(4): 483-49. DOI:10.1016/j.phytochem.2009.01.016

[4]. Ahmed, I.A.M., I. Morishima, E.E. Babiker and N. Mori, 2009b. Characterisation of partially purified milk clotting enzyme from SolanumdubiumFresen seeds. Food Chemistry, 116(2): 395-400. DOI:10.1016/j.foodchem.2008.11.072

[5]. Asif-Ullah, M., Kim, K. S., \& Yu, Y. G. (2006). Purification and characterization of a serine protease from CucumistrigonusRoxburghi. Phytochemistry, 67, 870-875. Cabezas, L., Esteban, M. A., \& Marcos, A. (1981). Agar gel diffusion of Cynarahumilis (L.) proteinases and other enzymes. Alimentaria, 128, 17-22.

[6]. Caicedo, A. L. and Schaal B. A. (2004). Heterogeneous evolutionary processes affect 'R' gene diversity in natural populations of Solanumpimpinellifolium. Proceedings of the National Academy of Sciences, USA 101 (50): 17444-17449.

[7]. Dawla, A.A. 2001. Studies on a rennet substitute from Solanumdubiumfrozen (Gubbain) PhD. Thesis, University of Khartoum, Sudan.

[8]. Daunay, M. C. and Chadha, M. L. (2004). SolanummelongenaL. In: Gruben GJH \& Denton OA (eds.) Plant Resources of Tropical Africa 2. Vegetables. Wageningen: PROTA Foundations/ Backhuys Publishers /CTA. p: 21-23.

[9]. EL-Khair, Y.M. \&Salih, M.H. 1982. Investigation of certain plant used in Sudanese folk medicinal. Journal of African Medicinal Plants 5: 247-226.

[10]. El owni,O.A.O., Kheir, S.E.O.; Abdalla, M.O.M. (2011). Extraction and Characterization of Solanumdubium(Gubbain) Fruit Extract. Australian J. of Basic and Applied Sciences, 5 (9): 213-218.

[11]. Esteves, C.L.C.; Lucey, A.J.; Wang, T. and Pires, V.M.E. (2003). Effect of pH on the gelation properties of skim milk gels made from plant coagulants and chymosin. Journal of Dairy Science, 86 (8): 2558-2567.

[12]. Harbone, B. (1984). Phytochemical methods. 2nd. New York, Champan Hall, 4, 4-7. Kahkonen, M. P., Hopia, A. I., Vuorela, H. J., Rauha, J. P., Pihlaja, K., Kujala T.

[13]. Isam, A.M.A., Isao, M., Elfadil, E.B. \&Nobuhiro, M. 2009. Characterization of partially purified milk-clotting enzyme from Solanumdubiumfrozen seeds. Food Chemistry 116: 395-400.

[14]. Jingkai, Z., Edward, L.D. \& Calvin, G.M. 2005. Factors affecting eastern black nightshade (Solanumptycanthum) seed germination. Weed Science 53(5): 651-656.

[15]. Kheir, O.E.S.; El Owni, O.A.O. and Abdalla, M.O.M. (2011). Comparison of quality of Sudanese white cheese (Gibnabayda) manufactured with Solanumdubium fruit extract and rennet. Pakistan Journal of Nutrition, 10 (2): 106-111.

[16]. Molan, P. C. (1995). The antibacterial properties of honey. Chemistry in New Zealand, 59(4):10-14.

[17]. Mohamed, B.E. and E.S. Habbani, 1996. Utilization of SolanumdubiumFresen for cheese making. U.K.J. Agric. Sci., 4(2): 139148.Nouani, A., E. Dako, A.

[18]. Olmstead, R. G. and Palmer J. D. (1997). Implications for the phylogeny, classification, and biogeography of Solanum from cpDNA restriction site variation. Syst Bot 22(1): 19-29.

[19]. Osman, D.A.A., 2001. Studies on a rennet substitute from SolanumdubiumFresen (Gubbain). Ph.D. Thesis, University of Khartoum, Sudan.

[20]. Suleiman, Y.R., El-Imam, Y.M. \&Allagabo, H. I. 1988. Milk coagulating properties of Solaniumincanum. Sudan Journal Animal Production 1: 109-112.

[21]. Sukhdev. S. H; Suman. P. S. K; Gennaro L.; Dev. D. R. (2008). Extraction technologies for medicinal and aromatic plants. United Nation Industrial Development Organization and the International Center for Science and High Technology. 116.

[22]. Talib, A.M.; Abubakar, M.M.; Jideani, I.A. and Hassan, A. (2009). Use of jiben seeds extract to manufacture soft white cheese. American Journal of Applied Science, 6 (4): 551-554.lipolysis and proteolysis of vacuumpacked Turkish Kashar cheese during ripening.Journal of Central European Agriculture, 7 (3): 459-464.

[23]. Tarakci, Z. and Kucukoner, E. (2006). Changes on physicochemical,Walde, P., L.L Pier and P. Sandro, 1984. Proteolytic sunflower seeds (Helianthus annus L.),

[24]. J. Agric. Food Chem., 32(2): 322-329. DOI: 10.1021/jf00122a036 Wang, Y., O. Cheng, Z. Ahmed, X. Jiang and 
[25]. Wang, Y., O. Cheng, Z. Ahmed, X. Jiang and X. Bai, 2009. Purification and partial characterization of milk-clotting enzyme extracted from glutinous rice wine mash liquor. Korean Journal of Chemical Engineering: 1313-1318. DOI: 10.2478/s11814-009$0225-4$

[26]. Yadav, S. C., \&Jagannadhan, M. M. V. (2006). Highly stable glycosylated serine protease from medicinal plant Euphorbia milii. Phytochemistry, 67, 1414-1426.

[27]. Yamagata, H., Ueno, S., \& Iwasaki, T. (1989). Isolation and characterization of a possible native cucumisin from developing melon fruits and its limited

[28]. autolysis to cucumisin. Agriculture and Biological Chemistry, 53, 1009-1017.

[29]. Yousif, B.H.; McMahon, J.D. and Shammet, M.K. (1996). Milk clotting enzyme from Solanumdubium plant. International Dairy Journal, 6 (6): 637-644. 